\title{
Evaluation of Phenotypic Diversity by Use of Variable Analysis Multi of Various Populations of Oak Cork (Quercus suber L.) in Tunisia
}

\author{
Abdessalem Abdessamad1,2*, Imen Dhib'1, Ghada Baraket², Mustapha Ksontini1, \\ Amel Salhi-Hannachi ${ }^{2}$ \\ ${ }^{1}$ Laboratory of Physiology and Ecology Forester, National Institute Research in Agricultural Engineering, \\ Water and Forest, INRGREF, Tunis, Tunisia \\ ${ }^{2}$ Laboratory of Molecular Genetics, Immunology \& Biotechnology, Faculty of Sciences of Tunis, Campus \\ University, Tunis, Tunisia \\ Email: ${ }^{*}$ abdou.slouma@yahoo.fr
}

Received 6 July 2014; revised 8 August 2014; accepted 17 August 2014

Copyright (C) 2014 by authors and Scientific Research Publishing Inc.

This work is licensed under the Creative Commons Attribution International License (CC BY).

http://creativecommons.org/licenses/by/4.0/

(c) (i) Open Access

\section{Abstract}

Populations of oak cork (Quercus suber L.) originated from different areas in Tunisia were analysed based on morphological characters to assess the overall degree of phenotypic variability, to detect similarities between the genotypes and to evaluate significant forest features. One-way ANOVA analysis shows a significant difference between oak cork populations and demonstrates that parameters measured on leaves show an important degree of variability and permit to discriminate oak cork individuals. Vegetative variables are leaf length, leaf width, petioles length, number of leaf veins, petioles width, spines number, leaf area, length nipples, diameter nipples, weight nipples, and height trees. Diameter trees were scored and subjected to multivariate analysis. Results showed a considerable diversity among local germoplasme of oak cork. Principal component analysis (PCA) revealed that the characters related to the length and width of the sheets and the nipples accounted for a large proportion of the observed variability. Cluster analysis showed a typically continuous phenotypic diversity among oak cork accessions, and little associations between accessions from same geographic origin. Also, some heterogeneity within accessions that received the same denomination was evidenced. The variability observed between different populations is attached to phenotypic characters which depend primarily on two factors, gene and environment.

${ }^{*}$ Corresponding author.

How to cite this paper: Abdessamad, A., Dhib, I., Baraket, G., Ksontini, M. and Salhi-Hannachi, A. (2014) Evaluation of Phenotypic Diversity by Use of Variable Analysis Multi of Various Populations of Oak Cork (Quercus suber L.) in Tunisia. Open Journal of Ecology, 4, 861-872. http://dx.doi.org/10.4236/oje.2014.414072 


\section{Keywords}

\section{Quercus suber L., Populations, Phenotypic Study, Variability, Tunisia}

\section{Introduction}

The oak cork (Quercus suber L.) $(2 \mathrm{n}=24)$ is a Mediterranean species, which has a great ecological and socioeconomic interest. Oak groves are seldom in a stable state everywhere in the world, but are subjected to many gradual changes. They sometimes undergo catastrophic dysfunctions and then present strong reductions of growth, and damage in the crown. Because of the significant value of the products of the oak groves (wood of high quality, cork) and their ecological importance and landscape, the oak groves dominate of vast wide Mediterranean zones and constitute a significant component of landscapes apart from the zones of mountains; such dysfunctions raise a great concern among ecologists and foresters.

In Tunisia this indigenous leafy species occupies considerable surfaces in Kroumirie and Mogods about 127,000 ha in 1950 [1]; since the last decades, a worrying regression which was estimated at $1.22 \%$ of the surface per year [2]. The oak cork is characterized of a great polymorphism particularly in leaves and fruits. It has a great genetic variability which results in morphological differences between individuals and ecotypes. Thus technological qualities of cork and its speedily increase appear to strongly depend on the genetic factors [3]. [4] reported that the oak cork constituted definitely distinct races according to areas: the Numidia oak cork of Algeria and Tunisia, the Atlantic oak cork of Morocco, and the oak cork of the Western South of France with bi-annual maturation and more resistant to the cold; this confirmed great genetic richness of the oak cork to which primarily contributed cross-fertilization character of the species.

It can hybrid with the holm oak and this confers to him a great ecological plasticity and a greater adaptability in the mediums [3].

The production of cork shows variability between trees of same oak forest in term of the annual growth and quality; the variability of settlements shows the dominating effect of the tree like origin variability [5].

This article describes the evaluation of morphological variations which is based on the observation and the measurement of the morphological criteria on the leaves and on the fruit of oak cork populations in Tunisia. The principal objectives of this study consist to detect genetic ratios among cultivars, to determine total degree of polymorphism of this character, and to evaluate significant forest features for the classification of oak cork. The understanding of genetic variability and suitable identification of oak cork cultivar constitutes essential stages with regard to develop multiples strategies. Results obtained from these markers are compared and discussed in order to start an improvement program of this species.

\section{Materials and Methods}

\subsection{Plant Material and Measurements}

\subsubsection{Plant Material}

A total of 180 wild cork oak trees (Quercus suber L.) were inventoried from different locations in Kroumirie, Mogods and Cap Bon in Tunisia (15 individuals from each populations of Hammam Bourguiba [HB], Dar Fatma [DF], Oued Zeen [OZ], Aîn Zana [AZ], Mejen Essef [ME], Béni Mtir [BM], Djebel Zouza [DZ] (Ain Draham), El Feidja [EF] (Gar Dimaou), Bellif [B] (Nefza), Djebel Khroufa [DK] (Tabarka), Keff El Rand [KR] (El Haouaria) and Hammam Jdidi [HJ] (Hammamet) (Table 1 and Table 2). The choice of the sites was carried out according to the geographical distribution, the bioclimat and the relief. The plant material consisted in leaves and nipples randomly taken from adult cork oak trees (Quercus suber L.) and used to undergo a morphological study.

\subsubsection{Morphological Characters}

Morphological characterization of each individual was according to describe vegetative characters of oak cork to namely sheets and fruits as well as the growth of the trees (Table 3). These are reported as part of standard descriptors of oak cork [6]. 
Table 1. Characteristics geographical, bioclimatic and relief of different populations of oak cork (Quercus suber L.) in Tunisia.

\begin{tabular}{|c|c|c|c|c|c|c|c|}
\hline Site & Abbreviation & Area & $\begin{array}{c}\text { Geographical } \\
\text { distribution }\end{array}$ & $\begin{array}{c}\text { Bioclimat } \\
\text { (bioclimatic stage) }\end{array}$ & Relief & Altitude (m) & $\begin{array}{c}\text { Characteristics } \\
\text { geographical }\end{array}$ \\
\hline El Feidja & EF & Ghardimaou & $\begin{array}{c}\text { Western north } \\
\text { (Kroumirie) }\end{array}$ & $\begin{array}{l}\text { Wet superior at } \\
\text { moderate winter }\end{array}$ & Montagne & $780 \mathrm{~m}$ & $\begin{array}{c}32.43^{\circ} 84^{\prime} 22^{\prime \prime} \mathrm{E} \\
40.40^{\circ} 26^{\prime} 7^{\prime \prime N}\end{array}$ \\
\hline Beni M’ttir & BM & Ain Drahem & $\begin{array}{c}\text { Western north } \\
\text { (Kroumirie) }\end{array}$ & $\begin{array}{l}\text { Wet superior at } \\
\text { moderate winter }\end{array}$ & Montagne & $800 \mathrm{~m}$ & $\begin{array}{c}32.47^{\circ} 48^{\prime} 36^{\prime \prime} \mathrm{E} \\
40.65^{\circ} 89^{\prime} 8^{\prime \prime N}\end{array}$ \\
\hline $\begin{array}{l}\text { Hammam } \\
\text { Bourguiba }\end{array}$ & HB & Ain Drahem & $\begin{array}{l}\text { Western north } \\
\text { (Kroumirie) }\end{array}$ & $\begin{array}{l}\text { Wet superior at } \\
\text { moderate winter }\end{array}$ & Montagne & $570 \mathrm{~m}$ & $\begin{array}{c}32.46^{\circ} 76^{\prime} 08^{\prime \prime} \mathrm{E} \\
40.71^{\circ} 96^{\prime} 0 " \mathrm{~N}\end{array}$ \\
\hline Dar Fatma & DF & Ain Drahem & $\begin{array}{c}\text { Western north } \\
\text { (Kroumirie) }\end{array}$ & $\begin{array}{l}\text { Wet superior at } \\
\text { moderate winter }\end{array}$ & Montagne & $909 \mathrm{~m}$ & $\begin{array}{c}32.47^{\circ} 84^{\prime} 09^{\prime \prime} \mathrm{E} \\
40.73^{\circ} 59^{\prime} 6^{\prime \prime N}\end{array}$ \\
\hline Oued Zena & $\mathbf{O Z}$ & Ain Drahem & $\begin{array}{l}\text { Western north } \\
\text { (Kroumirie) }\end{array}$ & $\begin{array}{l}\text { Wet superior at } \\
\text { moderate winter }\end{array}$ & Montagne & $675 \mathrm{~m}$ & $\begin{array}{c}32.48^{\circ} 22^{\prime} 49^{\prime \prime} \mathrm{E} \\
40.75^{\circ} 63^{\prime} 0 " \mathrm{~N}\end{array}$ \\
\hline Mejen Essef & ME & Ain Drahem & $\begin{array}{c}\text { Western north } \\
\text { (Kroumirie) }\end{array}$ & $\begin{array}{l}\text { Wet superior at } \\
\text { moderate winter }\end{array}$ & Montagne & $800 \mathrm{~m}$ & $\begin{array}{l}32.48^{\circ} 17^{\prime} 17^{\prime \prime} \mathrm{E} \\
40.69^{\circ} 20^{\prime} 4 " \mathrm{~N}\end{array}$ \\
\hline Aîn Zana & $\mathbf{A Z}$ & Bouselm & $\begin{array}{l}\text { Western north } \\
\text { (Kroumirie) }\end{array}$ & $\begin{array}{l}\text { Wet superior at } \\
\text { moderate winter }\end{array}$ & Montagne & $851 \mathrm{~m}$ & $\begin{array}{c}32.48^{\circ} 77^{\prime} 03^{\prime \prime} \mathrm{E} \\
40.64^{\circ} 69^{\prime} 4^{\prime \prime N}\end{array}$ \\
\hline Djebel Zouza & DjZ & Nefza & $\begin{array}{c}\text { Western north } \\
\text { (Kroumirie) }\end{array}$ & $\begin{array}{l}\text { Wet superior at } \\
\text { moderate winter }\end{array}$ & Montagne & $542 \mathrm{~m}$ & $\begin{array}{c}32.49^{\circ} 96^{\prime} 49^{\prime \prime} \mathrm{E} \\
40.77^{\circ} 41^{\prime} 2^{\prime \prime N}\end{array}$ \\
\hline Keff El Rand & KR & Haouaria & $\begin{array}{l}\text { Northeast } \\
\text { (Cap Bon) }\end{array}$ & $\begin{array}{l}\text { Sub-wet superior } \\
\text { at hot winter }\end{array}$ & Montagne & $642 \mathrm{~m}$ & $\begin{array}{c}32.65^{\circ} 77^{\prime} 63^{\prime \prime} \mathrm{E} \\
40.77^{\circ} 15^{\prime} 8^{\prime \prime} \mathrm{N}\end{array}$ \\
\hline Hammam Jdidi & HJ & Hammamet & $\begin{array}{l}\text { Northeast } \\
\text { (Cap Bon) }\end{array}$ & $\begin{array}{l}\text { Semi-arid lower } \\
\text { than hot winter }\end{array}$ & Montagne & $174 \mathrm{~m}$ & $\begin{array}{c}32.62^{\circ} 08^{\prime} 79^{\prime \prime} \mathrm{E} \\
40.35^{\circ} 84^{\prime} 9 " \mathrm{~N}\end{array}$ \\
\hline Djebel Khroufa & DjK & Tabarka & $\begin{array}{l}\text { Western north } \\
\text { (Mogods) }\end{array}$ & $\begin{array}{l}\text { Wet inferior at } \\
\text { hot winter }\end{array}$ & Chaine tellienne & $160 \mathrm{~m}$ & $\begin{array}{c}32.49^{\circ} 41^{\prime} 25^{\prime \prime} \mathrm{E} \\
40.90^{\circ} 49^{\prime} 5^{\prime \prime N}\end{array}$ \\
\hline Bellif & B & Tabarka & $\begin{array}{l}\text { Western north } \\
\text { (Mogods) }\end{array}$ & $\begin{array}{l}\text { Wet inferior at } \\
\text { hot winter }\end{array}$ & Chaine tellienne & $88 \mathrm{~m}$ & $\begin{array}{c}32.50^{\circ} 79^{\prime} 87^{\prime \prime} \mathrm{E} \\
40.98^{\circ} 60^{\prime} 9^{\prime \prime} \mathrm{N}\end{array}$ \\
\hline
\end{tabular}

To study the morphological variability of Quercus suber 50 leaves were randomly taken at different part of the tree and thirteen vegetative variables (leaf length, leaf width, petioles length, numbers of leaf veins, petioles width, spines numbers, leaf area, length nipples, diameter nipples, weight nipples, height trees, diameter trees) were measured. All morphmetric measurements were taken using a Vernier caliper with digital display. The leaf areas were calculated using Microtech Scanmaker HP SCANJET G2710 scanner and were measured by image analysis logiciel (Optimas V6.0).

\subsection{Analysis of Morphological Data}

In order to elucidate genetic variability and to establish relationships between trees, several statistical procedures were conducted. Phenotypic data were used to approximate contribution of the measured leaves, nipples and trees traits in the genetic diversity among the considered individuals. Data were computed using the SPSS software (Statistical Package for the Social Sciences, version V.17.) to achieve one-way analysis of variance (ANOVA) and XLSTAT software to achieve principal components analysis (PCA) as a multivariate analysis. The PCA analysis was applied to assess differences between individuals and elucidate partitioning of phenotypic variability at inter-populations level. Parameters means were compared by DUNCAN'S multiple range test $(P<$ 0.05) [7] (Table 4). 
Table 2. Measured vegetative characters of oak cork (Quercus suber L.) in Tunisia. Leaf, nipples and trees characters retained for the study of oak cork (Quercus suber L.) populations diversity in Tunisia.

\begin{tabular}{cccc}
\hline Parameter & Abbreviation & Unit & Character \\
\hline LOFE & $\mathrm{cm}$ & Leaf length \\
LAFE & $\mathrm{cm}$ & Leaf width \\
LLOA & - & Length/width of leaf \\
Leaf descriptors & LOPE & $\mathrm{mm}$ & Petioles length \\
& NBNV & - & Numbers of leaf veins \\
& LAPE & $\mathrm{mm}$ & Petioles width \\
& NBEP & - & Spines numbers \\
& SRFO & $\mathrm{cm}{ }^{2}$ & Leaf area \\
LOGL & $\mathrm{cm}$ & Length nipples \\
& DIGL & $\mathrm{cm}$ & Diameter nipples \\
Trees descriptors & POID & $\mathrm{g}$ & Weight nipples \\
& HAU & $\mathrm{m}$ & Height trees \\
& DIA & $\mathrm{cm}$ & Diameter trees \\
\hline
\end{tabular}

Table 3. Mean values of measured traits in 12 cork oak accessions. (See Table 2 and Table 3 for cultivars and parameters labels respectively.)

\begin{tabular}{cccccccccccccc}
\hline & LOFE & LAFE & LLOA & LOPE & NBNV & LAPE & NBEP & SRFO & LOGL & DIGL & POID & HAU & DIA \\
\hline HB & 5.841 & 3.265 & 1.818 & 10.251 & 11.280 & 0.989 & 11.430 & 4.51 & 3.124 & 1.9341 & 5.384 & 8.500 & 33.233 \\
DF & 5.436 & 3.082 & 1.7818 & 11.200 & 11.120 & 8.462 & 10.130 & 5.402 & 3.284 & 1.586 & 5.696 & 7.420 & 35.600 \\
OZ & 5.257 & 2.709 & 1.9678 & 8.770 & 10.180 & 9.030 & 9.350 & 5.240 & 2.764 & 1.488 & 3.825 & 9.014 & 44.479 \\
AZ & 6.508 & 3.412 & 1.967 & 12.500 & 10.590 & 8.967 & 9.470 & 4.988 & 2.985 & 1.542 & 4.527 & 7.172 & 34.562 \\
ME & 6.008 & 3.362 & 1.802 & 12.170 & 11.790 & 9.680 & 9.190 & 4.858 & 3.043 & 1.556 & 4.951 & 10.013 & 51.539 \\
BM & 5.632 & 3.094 & 1.841 & 11.360 & 11.080 & 7.607 & 9.900 & 4.958 & 3.104 & 1.598 & 5.430 & 10.376 & 38.581 \\
DjZ & 6.100 & 3.092 & 2.014 & 11.700 & 12.640 & 9.475 & 11.480 & 4.222 & 3.715 & 1.656 & 7.031 & 6.777 & 38.037 \\
EF & 5.105 & 2.817 & 1.833 & 11.880 & 10.950 & 7.408 & 9.960 & 5.255 & 3.610 & 1.404 & 4.878 & 9.407 & 41.008 \\
DjK & 5.820 & 3.102 & 1.898 & 12.750 & 11.260 & 9.219 & 10.790 & 5.157 & 3.317 & 1.716 & 5.763 & 8.733 & 38.800 \\
B & 5.424 & 3.148 & 1.742 & 10.035 & 10.530 & 8.011 & 10.200 & 4.749 & 3.587 & 1.774 & 7.562 & 7.367 & 44.6181 \\
KR & 5.759 & 3.211 & 1.824 & 10.120 & 11.420 & 10.105 & 10.440 & 5.843 & 3.351 & 1.878 & 6.736 & 9.120 & 24.066 \\
HJ & 5.493 & 3.073 & 1.804 & 9.570 & 10.665 & 1.2084 & 10.024 & 4.997 & 3.058 & 1.698 & 5.662 & 6.817 & 21.600 \\
\hline
\end{tabular}

The Euclidean distance were estimated between individuals and a hierarchical cluster was constructed according to Ward's method [8] by module in the statistical packages [9] to establish relationships among Tunisian oak trees.

\section{Results}

Morphological parameters corresponding to biological characteristics, growth of the tree leaves, and fruit were measured in order to describe the genetic diversity and its partitioning. 
Table 4. Result of Duncan test (0.05) conducted on morphological characters.

\begin{tabular}{|c|c|c|c|c|c|c|c|c|c|c|c|}
\hline B & DF & $\mathbf{K R}$ & DZ & BM & $\mathbf{H J}$ & HB & DjK & $\mathbf{O Z}$ & EF & $\mathbf{A Z}$ & ME \\
\hline \multicolumn{12}{|c|}{ Leaf length (cm) } \\
\hline 5.493 & 5.840 & 5.424 & 5.820 & 5.257 & 5.632 & 6.100 & 5.436 & 5.105 & 6.000 & 6.508 & 5.759 \\
\hline \multicolumn{12}{|c|}{ Leaf width (cm) } \\
\hline 3.072 & 3.265 & 3.148 & 3.102 & 2.709 & 3.094 & 3.092 & 3.082 & 2.817 & 3.362 & 3.412 & 3.211 \\
\hline \multicolumn{12}{|c|}{ Length/width of leaf } \\
\hline 1.803 & 1.817 & 1.741 & 1.897 & 1.967 & 1.841 & 2.013 & 1.781 & 1.833 & 1.801 & 1.967 & 1.823 \\
\hline \multicolumn{12}{|c|}{ Petioles length (mm) } \\
\hline 9.569 & 10.251 & 10.035 & 12.750 & 8.770 & 11.360 & 11.700 & 11.200 & 11.880 & 12.170 & 12.500 & 10.120 \\
\hline \multicolumn{12}{|c|}{ Numbers of leaf veins (leaf veins) } \\
\hline 10.665 & 11.280 & 10.530 & 11.260 & 10.180 & 11.080 & 12.640 & 11.120 & 10.950 & 11.790 & 10.590 & 11.420 \\
\hline \multicolumn{12}{|c|}{ Petioles width (mm) } \\
\hline 1.208 & 0.988 & 8.011 & 9.219 & 9.030 & 7.607 & 9.475 & 8.462 & 7.408 & 9.680 & 8.967 & 10.105 \\
\hline \multicolumn{12}{|c|}{ Spines numbers (spines) } \\
\hline 10.023 & 11.430 & 10.200 & 10.790 & 9.350 & 9.900 & 11.480 & 10.130 & 9.960 & 9.190 & 9.470 & 10.440 \\
\hline \multicolumn{12}{|c|}{ Leaf area $\left(\mathrm{cm}^{2}\right)$} \\
\hline 4.996 & 4.511 & 4.749 & 5.157 & 5.239 & 4.958 & 4.221 & 5.401 & 5.254 & 4.858 & 4.988 & 5.843 \\
\hline \multicolumn{12}{|c|}{ Length nipples (cm) } \\
\hline 3.058 & 3.124 & 3.585 & 3.317 & 2.763 & 3.103 & 3.714 & 3.284 & 3.610 & 3.042 & 2.982 & 3.351 \\
\hline \multicolumn{12}{|c|}{ Diameter nipples (cm) } \\
\hline 1.698 & 1.934 & 1.774 & 1.715 & 1.487 & 1.598 & 1.656 & 1.586 & 1.404 & 1.551 & 1.541 & 1.877 \\
\hline \multicolumn{12}{|c|}{ Weight nipples (g) } \\
\hline 5.661 & 5.384 & 7.558 & 5.763 & 3.824 & 5.430 & 7.030 & 5.696 & 4.878 & 4.950 & 4.513 & 6.736 \\
\hline \multicolumn{12}{|c|}{ Height trees (m) } \\
\hline 7.363 & 7.333 & 6.776 & 10.376 & 8.500 & 9.406 & 8.733 & 9.014 & 9.120 & 6.816 & 7.172 & 10.013 \\
\hline \multicolumn{12}{|c|}{ Diameter trees $(\mathrm{cm})$} \\
\hline 44.618 & 35.600 & 38.037 & 38.580 & 33.233 & 41.007 & 38.800 & 44.479 & 24.066 & 21.600 & 34.561 & 51.539 \\
\hline
\end{tabular}

B: Bellif; DF: Dar Fatma; KR: Keff Rand; DZ: Djebel Zouza; BM: Béni Mtir; HJ: Hammam Jdidi; HB: Hammam Bourguiba; DjK: Djebel Khroufa; OZ: Oued Zen; EF: El Feidja; AZ: Ain Zana; ME: Mejen Essef.

\subsection{One-Way Variance Analysis: ANOVA}

The ANOVA analyses applied on the morphological parameters enabled the determination of the most discriminating variables between the studied populations. The characters used are very efficient to estimate phenotypic variability of these populations.

The one-way ANOVA analysis showed a signifying diversity between cultivars, except for four parameters (length/width of leaf, petioles length, leaf area, diameter nipples). The ANOVA shows significant differences among cultivars for 9 traits out of 13. Table 5 illustrates that out of the 13 parameters 6 were highly significant (leaf length, numbers of leaf veins, petioles width, length nipples, weight nipples, height trees and 3 were significant: leaf width, spines numbers and diameter trees). We note that the most discriminator parameters are those related to leaves and to nipples especially the length and weight and trees especially on height (Table 5). 
Table 5. One-way analyses of variance (ANOVA) applied on quantitative parameters referring to leaf. Nipples and trees descriptors.

\begin{tabular}{cccc}
\hline Morphological traits & Mean square & F. observed & $\boldsymbol{P}$ \\
\hline Leaf length & 1535 & $4395^{* *}$ & 0.000 \\
Leaf width & 0.400 & $3008^{* *}$ & 0.002 \\
Length/width of leaf & 0.072 & $2125^{\mathrm{NS}}$ & 0.024 \\
Petioles length & 15,811 & $2202^{\mathrm{NS}}$ & 0.019 \\
Numbers of leaf veins & 4222 & $3830^{* *}$ & 0.000 \\
Petioles width & 96,429 & $59,571^{* *}$ & 0.000 \\
Spines numbers & 5469 & $2905^{*}$ & 0.002 \\
Leaf area & 1769 & $0.974^{\mathrm{NS}}$ & 0.475 \\
Length nipples & 0.818 & $24,721^{* *}$ & 0.000 \\
Diameter nipples & 0.245 & $2320^{\mathrm{NS}}$ & 0.013 \\
Weight nipples & 11,418 & $19,961^{* *}$ & 0.000 \\
Height trees & 4745 & $6517^{* *}$ & 0.000 \\
Diameter trees & 211,198 & $3810^{*}$ & 0.003 \\
\hline
\end{tabular}

${ }^{\mathrm{NS}}$ Non significant; "Significant; *High significant.

\subsection{Multivariate Analysis: Principal Component Analysis}

This method—carried out on covariance's matrix—provided a correlation matrix between the characters, as well as an individual's graphic representation in space which defined by the principal components.

Being given that the measuring units used vary from one character to another, it is essential to standardize the rough phenotypic data [10]. The reduced center matrix thus obtained was subjected to multivariate analysis. Table 3 summarizes the results of the principal component analyses. Furthermore, we have performed a PCA analysis taking into account the morphological parameters. Result of PCA analysis shows that $50.091 \%$ of the total variation was explained by the first two principal components (Figure 1).

The first two principal components accounted for $28.783 \%$, and $21.307 \%$, respectively, of the total variations among oak cork accessions of based on the fourteen vegetative traits. (Length of leaves) (LOFE) (width of leaves) (LAFE) (number of leaf veins) (NBNV) (number of spines) (NBEP) (lengths nipples) (LOGL) (diameter nipples) (DIGL) and (weight nipples) (POID) had strong positive charge, while (leaf area (SRFO) tree height (HAU), diameter of the trees (DIA)) had strong negative charges in the first principal component.

In the second component, the number of spines (NBEP), leaf area (SRFO), (diameter Nipples) (DIGL) and nipples' weight (POID) had negative charges, whereas leaves' length (LOFE), petiole's length (LOPE) petioles' widths (LAPE) and trees' diameter (DIA) showed strong positive charges.

The graphic representation of cultivars on the plan axes (1-2) presented in Figure 1 showed a significant opposition accessions of group IIa (DJ Zouza [DZ] and DJ Khroufa [DK]) and accessions of same group IIa (Oued Zen [OZ]) according to the first principal component.

Accessions of group IIa (DJ Zouza [DZ] and DJ Khroufa [DK]) are characterized by a length leaves, width leaf, petiole length, number of leaf veins; spines numbers, length nipples, diameter nipples and weight nipples were high positive charge, while, Oued Zen [OZ] has a larger height and diameter trees.

Moreover, individuals from populations of Dar Fatma [DF], El Keff Rand [KR], Bellif [B]; Hammam Bourguiba [HB], Hammam Jdid [HJ], Ain Zena [AZ], Méjen Essef [ME], Béni Mtir [BM] and El Feidja [EF] are shared between the two groups I and II (Figure 2).

In contrast, the accessions of group of (Dar Fatma [DF], El Keff Rand [KR], Bellif [B], Hammam Bourguiba [HB], and Hammam Jdid [HJ]) showed a significant opposition of accessions of group of (Ain Zena [AZ], Méjen Essef [ME], Béni Mtir [BM], and El Feidja [EF] above by the number of spines length, diameter and weight of nipples. 


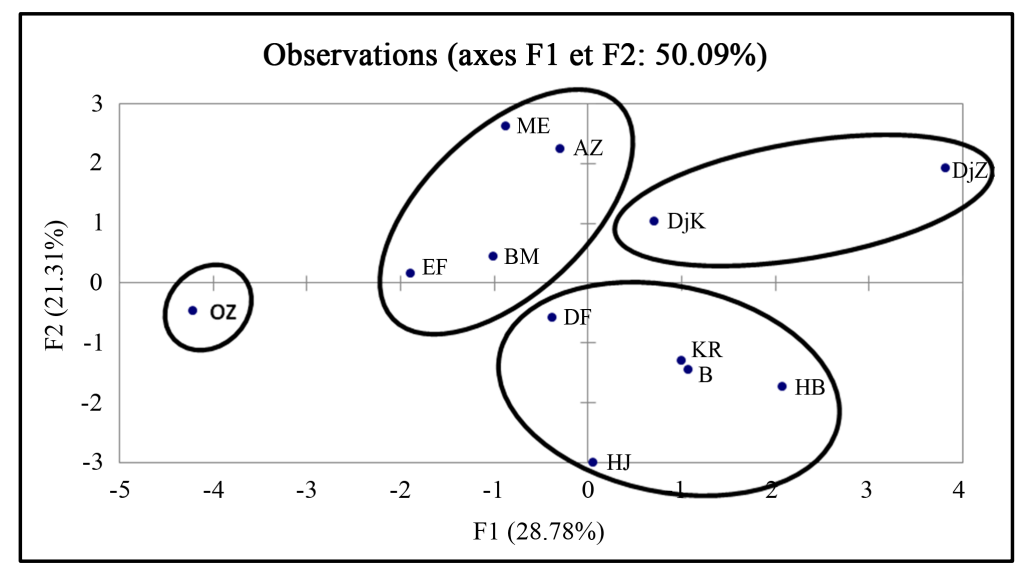

Figure 1. Representation of the projection of the populations in the plan 1-2 analysis in component principal.

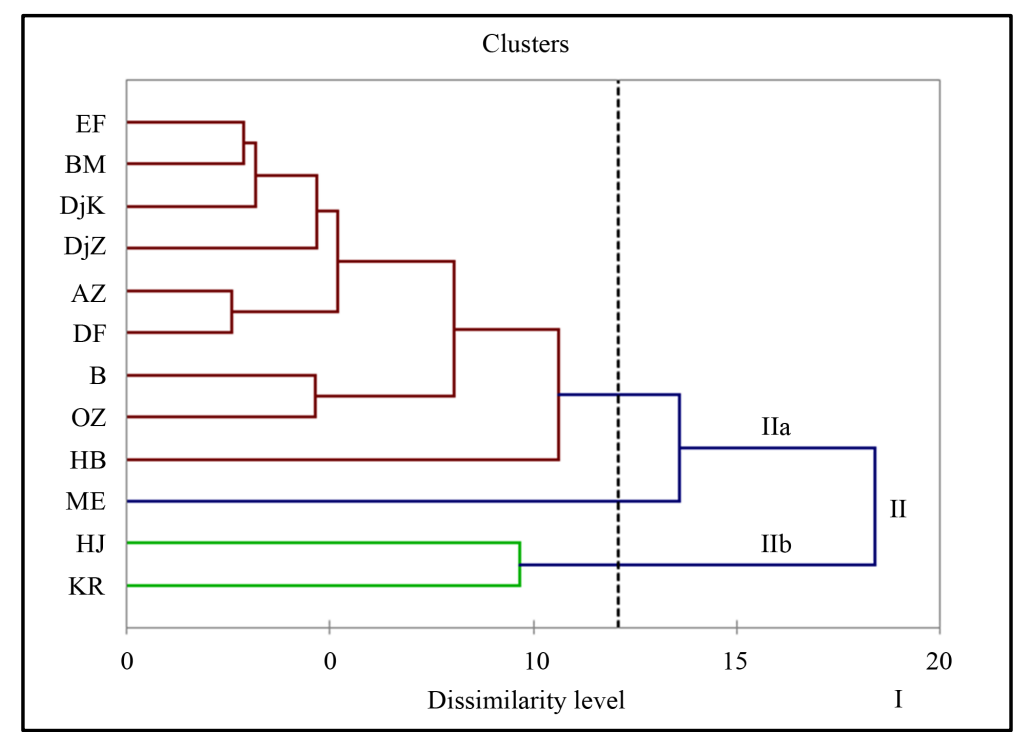

Figure 2. Hierarchical classification of the twelve populations of oak cork (Quercus suber L.) based on Euclidean distances applied on 13 morphological and dendrometric parameters.

The second axis opposes accessions of group IIa (DJ Zouza [DZ], and DJ Khroufa [DK]) with a great leaves length, leaves width, petiole length, petiole width, number of leaf veins, number of spines, lengths, diameter and weight of nipples and large accessions of group IIa (Oued Zen [OZ]) characterized by a large height and diameter trees (Figure 2).

\subsection{Correlation Matrix}

Table 5 shows the correlation matrix between the characters studied.

A high positive correlation ( 0.750 to 0.811 ) between the characters according to (Table 6):

- Leaf length was positively correlated to leaf dispatcher and petioles leaf length. Leaf dispatcher was positively correlated to petioles leaf length and nipples diameter. Petioles leaf length was positively correlated to numbers of veins. The number of veins was positively correlated to number of leaf spines and nipples length. The dispatcher of petioles of leaf was positively correlated to the diameter to the collets of young seedlings. The number of the spines was positively correlated to nipples diameter. The surface of leaf was positively correlated to the height of young seedlings. The nipples length was positively correlated to nipples weight. The nipples diameter was positively correlated to nipples weight. 
Table 6. Pearson's correlation matrix between the different characters in cork oak accessions. With the threshold of risk of $5 \%$.

\begin{tabular}{|c|c|c|c|c|c|c|c|c|c|c|c|c|c|}
\hline Variables & LOFE & LAFE & LLOA & LOPE & NBNV & LAPE & NBEP & SRFO & LOGL & DIGL & POID & HAU & DIA \\
\hline LOFE & 1.000 & & & & & & & & & & & & \\
\hline LAFE & 0.811 & 1.000 & & & & & & & & & & & \\
\hline LLOA & 0.441 & -0.165 & 1.000 & & & & & & & & & & \\
\hline LOPE & 0.527 & 0.418 & 0.204 & 1.000 & & & & & & & & & \\
\hline NBNV & 0.436 & 0.320 & 0.208 & 0.452 & 1.000 & & & & & & & & \\
\hline LAPE & 0.177 & -0.024 & 0.333 & 0.395 & 0.216 & 1.000 & & & & & & & \\
\hline NBEP & 0.146 & 0.084 & 0.109 & 0.033 & 0.556 & -0.292 & 1.000 & & & & & & \\
\hline SRFO & -0.362 & -0.226 & -0.251 & -0.143 & -0.397 & 0.306 & -0.418 & 1.000 & & & & & \\
\hline LOGL & -0.119 & -0.063 & -0.118 & 0.282 & 0.498 & 0.194 & 0.563 & -0.196 & 1.000 & & & & \\
\hline DIGL & 0.208 & 0.440 & -0.308 & -0.299 & 0.201 & -0.381 & 0.658 & -0.114 & 0.146 & 1.000 & & & \\
\hline POID & 0.046 & 0.239 & -0.295 & -0.042 & 0.426 & 0.069 & 0.586 & -0.198 & 0.750 & 0.604 & 1.000 & & \\
\hline HAU & -0.219 & -0.136 & -0.173 & 0.120 & 0.005 & 0.231 & -0.327 & 0.320 & -0.250 & -0.192 & -0.380 & 1.000 & \\
\hline DIA & -0.069 & -0.125 & 0.063 & 0.286 & 0.052 & 0.470 & -0.340 & -0.292 & 0.017 & -0.488 & -0.219 & 0.392 & 1.000 \\
\hline
\end{tabular}

The values in fat are different from 0 on a level of significance alpha $=0.05$.

A high negative correlation ( -0.488 to -0.024$)$ ia also to note between the characters according to (Table 6):

- The leaf length was negatively correlated to the surface of leaf, nipples length, the height and the diameter with the collets of young seedlings. Leaf dispatcher was negatively correlated to the width of the leaf, the surface of leaf, the nipples length, the height and the diameter with the collets of young seedlings. The number of veins was negatively correlated to the surface of the leaf. The width petioles leaf was negatively correlated to the number of the leaf spines and the diameter of nipples. The number of leaf spines was negatively correlated to the surface of the leaf, the height and the diameter with the collets of young seedlings. The surface of the leaf was negatively correlated to the length, the diameter and the weight of nipples, and to the diameter and to the collets of young seedlings. Nipples length was negatively correlated to height of young seedlings. The diameter of nipple was negatively correlated to height and diameter to the collets of young seedlings. The weight of nipple was negatively correlated to height and diameter to the collets of young seedlings.

\subsection{Analyze Canonical Discriminating}

\section{Euclidean Distance}

The Euclidean distances represent the extent of genetic separation between the groups of populations (Table 7) this information can be used to determine the crossings of the genotypes likely to give hybrids having more strength.

To identify the characters able to discriminate the 12 populations, averages and standard deviations of each character were calculated.

The obtained matrix exhibits genetic distances ranging from 2.593 to 31.432 and shows a high phenotypic diversity among the studied individuals. The lowest distance is observed between the individuals of [DF] and [AZ] populations. The distance that shows the maximum difference was noticed respectively between the individuals of $[\mathrm{ME}]$ and $[\mathrm{HJ}]$ populations.

The population of Méjen Essef [ME] is furthest away from the populations of Keff El Rand [KR] and Hammam Jdidi [HJ] and with distances respectively from 27,678 and 31,432. The most remarkable bringing together between populations exists between the population of Dar Fatma [DF] and the population of Ain Zena [AZ] with the weakest distance (about 2593 like between the population of Béni Mtir [BM] and the population of El Feidja 
Table 7. The Euclidean distances for the 12 populations of oak cork.

\begin{tabular}{|c|c|c|c|c|c|c|c|c|c|c|c|c|}
\hline \multicolumn{13}{|c|}{ Stamp proximity (Euclidean distance): } \\
\hline & HB & DF & $\mathbf{O Z}$ & $\mathbf{A Z}$ & ME & BM & DjZ & $\mathbf{E F}$ & DjK & B & $\mathbf{K R}$ & HJ \\
\hline HB & 0 & & & & & & & & & & & \\
\hline DF & 8153 & 0 & & & & & & & & & & \\
\hline $\mathbf{O Z}$ & 14,251 & 9650 & 0 & & & & & & & & & \\
\hline AZ & 8842 & 2593 & 10,887 & 0 & & & & & & & & \\
\hline ME & 20,552 & 16,305 & 8244 & 17,290 & 0 & & & & & & & \\
\hline BM & 8939 & 4333 & 7042 & 5631 & 13,209 & 0 & & & & & & \\
\hline DjZ & 10,265 & 3952 & 8888 & 5390 & 14,295 & 5051 & 0 & & & & & \\
\hline EF & 10,462 & 5986 & 5230 & 7258 & 10,929 & 2864 & 5665 & 0 & & & & \\
\hline DjK & 10,301 & 3955 & 7486 & 4999 & 12,972 & 2890 & 3270 & 3424 & 0 & & & \\
\hline B & 13,696 & 9343 & 4633 & 10,940 & 8512 & 7263 & 7469 & 5388 & 7007 & 0 & & \\
\hline KR & 13,123 & 11,893 & 20,791 & 11,358 & 27,678 & 14,936 & 14,463 & 17,395 & 15,051 & 20,803 & 0 & \\
\hline HJ & 11,898 & 15,877 & 24,384 & 15,483 & 31,432 & 18,586 & 18,772 & 20,701 & 19,364 & 24,097 & 9678 & 0 \\
\hline
\end{tabular}

[EF] with a distance about 2864. An ascending hierarchical classification of the populations was carried out thanks to the matrix of the Euclidean distances (Table 7 and Table 8).

\subsection{Cluster Analysis: Hierarchical Classification Method}

The cluster obtained in the basis of Hierarchical classification analysis [11] was constructed. Dissimilarity level ranged from 2.70 to 12.10 . Figure 1 shows two major clusters (I) and (II). The first one (I) is composed by trees from "Hammam Jdidi” [HJ] population originating from Hammamet, and from "Keff Rand” [KR] population originating from El Haouaria.

The second group (II) contains the remaining population. It is composed by two minor clusters (IIa) composed by trees from Hammam Bourguiba [HB], Dar Fatma [DF], Oued Zeen [OZ], Aîn Zana [AZ], Béni Mtir [BM], Djebel Zouza [DZ] populations originating from Ain Drahem, El Feidja [EF] population originating from Bouselm; Bellif [B] and Djebel Khroufa [DK] populations originating from (Tabarka); and clusters (IIb) composed by a single population Mejen Essef [ME] originating from Ain Drahem.

Within this group Aîn Zana [AZ] and Dar fatma [DF] population were very closely related with the lowest registered dissimilarity level $(\mathrm{d}=2.70)$. The same group of clusters IIa included all the 7 accessions; El Feidja [EF] originating from Bouselm and Béni Mtir [BM], Bellif [B], Hammam Bourguiba [HB] and Oued Zeen [OZ] originating from Ain Drahem; with accessions of Djebel Khroufa [DK] originating from (Tabarka) and accessions of Djebel Zouza [DZ] belonging to Nefza. Furthermore, Méjen Essef [ME] accession from Ain Drahem was very phenotypically different from the two other Keff El Rand [KR] originating from El Haouaria and Hammam Jdidi $[\mathrm{HJ}]$ originating from Hammamet. The topology cluster shows a considerable morphological variability no correlated to geographical origins of the prospected sites (Figure 2).

\section{Discussion}

The present study was carried out to evaluate genetic diversity and characterize the oak cork (Quercus suber L.) tree in 12 populations Tunisian using morphological parameters of leaves, nipples and trees.

Results exhibited considerable genetic variation among Tunisian oak cork populations. Similar data have been previously reported in oak cork accessions. Indeed, [12] bring back a high degree of phenotypical polymorphism in 26 sources of oak cork originating in Spain, Portugal, Italy, Morocco, Algeria and Tunisia by using seven morphological metric characters, considered to be discriminating related to characters of vegetative growth of oak cork. These authors also reported the utility to make the distinction between the sources of oak cork and to 
Table 8. Eigenvalues, proportion of variation and eigenvectors associated with the first three axes of the PCA in 12 cork oak accessions (Table 5 for parameters' label.)

\begin{tabular}{|c|c|c|c|c|c|c|}
\hline & \multicolumn{2}{|c|}{ PC1 } & \multicolumn{2}{|c|}{ PC2 } & \multicolumn{2}{|c|}{ PC3 } \\
\hline Eigenvalues variance & \multicolumn{2}{|c|}{3742} & \multicolumn{2}{|c|}{2770} & \multicolumn{2}{|c|}{1884} \\
\hline Variance proportion individual (\%) & \multicolumn{2}{|c|}{28,783} & \multicolumn{2}{|c|}{21,307} & \multicolumn{2}{|c|}{14,493} \\
\hline Cumulative (\%) & \multicolumn{2}{|c|}{28,783} & \multicolumn{2}{|c|}{50,091} & \multicolumn{2}{|c|}{64,584} \\
\hline \multirow{8}{*}{ Eigenvectors $^{\mathrm{a}}$} & var & e.i & var & e.i & var & e.i \\
\hline & NBNV & $(0.350)$ & LOFE & $(0.356)$ & LOFE & $(-0.442)$ \\
\hline & LAPE & $(-0.082)$ & LOPE & $(0.474)$ & LAFE & $(-0.415)$ \\
\hline & NBEP & $(0.426)$ & LAPE & $(0.399)$ & LLOA & $(-0.121)$ \\
\hline & SRFO & $(-0.264)$ & NBEP & $(-0.121)$ & LOGL & $(0.535)$ \\
\hline & DIGL & $(0.351)$ & SRFO & $(-0.144)$ & DIGL & $(-0.154)$ \\
\hline & POID & $(0.397)$ & DIGL & $(-0.298)$ & POID & $(0.304)$ \\
\hline & HAU & $(-0.249)$ & POID & $(-0.139)$ & DIA & $(0.257)$ \\
\hline
\end{tabular}

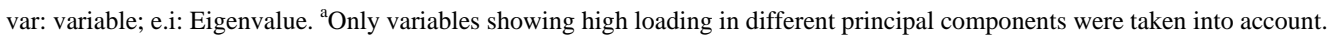

validate the morphological metric approach which is a tool for the early selection of sources for the deforestation.

The accessions indicated that the characters (lengths of leaves); (widths of leaves); (number of the veins' leaves); (spines' number); (lengths' nipples); (diameter's nipples) and (weight’s nipples); (petioles' lengths); (petioles' widths) and (collet's diameter of seedlings) accounted for a large proportion of the observed variability.

In addition, the coefficient of correlation of Pearson revealed that certain characters were largely correlated the ones with the others. A strong correlation enters leaves length with dispatcher of leaves or between nipples length and weight of nipples length.

The typological analysis showed that a phenotypic diversity which generally continuous, characterizes the local oak cork germoplasm. The topology of the derived dendrogram strongly supported this assumption.

Moreover, the results of typological analysis UPGMA showed an association between the accessions which show similar characteristics, such as the accessions of Keff El Rand [KR] (El Haouaria) and Hammam Jdidi [HJ] (Hammamet) on the one hand and the accessions of El Feidja [EF] (Bouselm); Djebel Khroufa [DK] (Tabarka); Béni Mtir [BM]; Aîn Zana [AZ]; Dar Fatma [DF]; Bellif [B]; Oued Zeen [OZ]; Hammam Bourguiba [HB] (Ain Drahem) and Dj Zouza [DZ] (Nefza) on the other hand. The accession of Méjen Essef [ME] (Ain Drahem) presents a class independent of the other accessions.

This diversity of the populations in the morphological characters, like generally reported to many species of forest trees, can result from type to cross the reproductive system and intense gene flows between the species that were shown in particular between the holm oak and cork oak [13]. Indeed, the biotic effect was implied like factor responsible for the regeneration of cork oak loss [14] because the intensity of these various types of the predation can vary spatially and temporally between the populations.

This source of regression in the regeneration of the cork oak can act like a powerful source of diversification of selection among the populations of Quercus suber L.

The results also revealed a phenotypic heterogeneity within the same species.

In the cork oak, $64.584 \%$ of the total genetic variation measured on the growth characteristics is ascribable to differentiation between the populations. This value higher than that was found by [12] (value of about 17.8\%) and by [15] (value of about 11\%) and was relatively higher than the average: 7\% obtained more than 25 species of oaks studied for the polymorphism enzyme [16], which suggests that the natural selection supported various phenotypes in different populations. Indeed, [17] show that the natural selection is a considerable source of differentiation between the populations. It has two possible explanations for this reason for variation: the populations of Quercus suber became differentiated because heterogeneity (monoclonal) of mode of selection, which 
led the population to its local optima, and/or differentiation, is a consequence of the genetic drift produced by the genic absence of flow between the populations, and by the events founders. One could expect geographically adjacent populations with the environment which have the same conditions and, possibly, abiotic similar selective pressures [18].

The effect of genotype is responsible for the phenotypic variability in cork oak in eastern Spain since two chlorotypes (chlorotype No. 21 this Spanish Catalonia and chlorotype No. 23, which differs from previous two mutations present in the pyrenees, subject to new results from cork of Spanish Catalonia, one can assume that the cork oak chlorotype characteristic of this region [19]. Sums in accordance with [20] which considers the hybridization as a rare occurrence, accidental and very low percentage of occurrence with respect to time of cohabitation. [21] think it is unusual to find more than 5 percent. 100 hybrids in a mixed population (though he identifies himself three out of twenty-five individuals, in Bagley Wood).

[22], assume that imperfect understanding more variable than is commonly believed specific characters, explain why some studies have determined to a significant degree hybrid (loc. cit.) in natural populations. This variability could be sure of genetic or phenotypic origin. Note that [23] showed strong intraspecific variability agglutinins leaves and fruits by location.

RUSHTON using a multi variable analysis. There are however studies that leaf traits, assuming they correlate well to the characters of seed heads. Now it is often because of contradictions between leaf traits and characters infructescences that botanists cannot determine with certainty an oak!

Morphological variation and field observations suggest that there is gene flow among the four taxa of the subgenus Quercus in the population sampled in this study, Gene flow is an important factor in population genetics, shopping the diversity of species [24] and [25]. This study suggests that in the twelve populations sampled (Hammam Bourguiba [HB], Dar Fatma [DF], Oued Zeen [OZ], Aîn Zana [AZ]; Mejen Essef [ME]; Béni Mtir [BM]; Djebel Zouza [DZ] (Ain Draham) El Feidja [EF] (Gar Dimaou); Bellif [B] (Nefza); Djebel Khroufa [DK] (Tabarka); Keff El Rand [KR] (El Haouaria) and Hammam Jdidi [HJ] (Hammamet) interspecific gene flow occurs and is associated with great morphological variation.

\section{Conclusions}

As a result of the present study, we can conclude that traits related to vegetative organs of Quercus suber L. show considerable phenotypic diversity in this important crop. Those related to the sizes from leaves, nipples and growth present the most discriminating value. A case of homonymy was detected in cultivar originating from Ain Drahem.

This study reveals considerable phenotypic (and presumably genetic) diversity among oak cork accessions, and accurate oak cork cultivars identification; however, it needs a large number of morphological markers and the exploration of other eco physiological, biochemical and molecular markers such as isozymes, AFLP fingerprinting, microsatellites and sequencing to analyze genotypic diversity.

\section{Acknowledgements}

This work was supported by grants of the National Institute of Research in Agricultural Engineering, Water and Drills by National Institute for Research in Rural Engineering, Water and Forestry (Institute Tunis Carthage), and the Faculty of Sciences of Tunis (University Tunis El Manar).

\section{References}

[1] Boudy, P. (1950) North-African Forestry Economics. Monograph and Treatment of the Forest Gasolines. Fasc. I, Vol. I, ED the Rose, Paris, 575 p.

[2] General Direction of Forests (1995) Results of First National Forest Inventory in Tunisia (I.F.N), Ceres Productions. Tunis.

[3] Louis, A. (2002) The subéraie, biodiversity and paysage. Ingenior CRP. PACA.

[4] Boudy, P. (1952) Guide of the Forester in North Africa. Rustic House, Paris, 505 p.

[5] Ferreira, A. and Pereira, F.L.H. (1999) Characterization of the Growth and the Quality of Cork in an Area of Production. Annals of Forest Science, 57, 187-193. http://dx.doi.org/10.1051/forest:2000169

[6] IPGRI (2005) Descriptor of the Date Palm (Phoenix dactylifera L.). Ipgri, Rome, Italie. Mars, Mr., Marrakchi, Mr., 
1999. The Diversity of the Grenade (Punica granatum L.)

[7] Dagnelie, P. (1975) Theorie et methodes statistiques, Applications agronomiques. Vol. 2. Les méthodes de l'inférence statistique. 2nd Edtion, Presses Agronomiques de Gembloux, Gembloux, 463 p.

[8] Ward Jr., J.H. (1963) Hierarchical Grouping to Optimize an Objective Function. Journal of the American Statistical Association, 58, 236-244. http://dx.doi.org/10.1080/01621459.1963.10500845

[9] XLSTAT (2012) Addinsoft TM Version 2012. www.xlstat.com/

[10] Humphreys. M.O. (1991) With Genetic Approach to Multivariate Differentiation of Perennial Ryegrass (Lolium perenne L.) Populations. Heredity, 66, 437-443. http://dx.doi.org/10.1038/hdy.1991.53

[11] Peeters, J.P. and Martinelli, J.A. (1989) Hierarchical Cluster Analysis Have Has Tool to Manages Variation in Germplasm Collections. Theoretical and Applied Genetics, 78, 42-48. http://dx.doi.org/10.1007/BF00299751

[12] Gandour, M., Khouja, M.L., Toumi, L. and Triki, S. (2007) Morphological Evaluation of Cork Oak (Quercus suber): Mediterranean Provenance Variability in Tunisia. Annals of Forest Science, 64, 549-555.

[13] Elena-Rossello, J.A., Lumaret, R., Cabrera, E. and Michaud, H. (1992) Evidence for Hybridization between Sympatric Holm-Oak and Cork-Oak in Spain Based on Diagnostic Enzyme Markers. Vegetation, 99-100, 115-118. http://dx.doi.org/10.1007/BF00118216

[14] Hasnaoui, B. (1998) Natural Regeneration of the Oak Cork: Difficulties and Proposals for Solutions.

[15] Toumi, L. and Lumaret, R. (1998) Allozyme Variation in Cork Oak (Quercus suber L.): The Role of Phylogeography and Genetic Introgression by Other Mediterranean Oak Species and Human Activities. Theoretical and Applied Genetics, 97, 647-656. http://dx.doi.org/10.1007/s001220050941

[16] Kremer, A. and Small, R.J. (1993) Gene Diversity in Natural Populations of Oak Species. Annals of Forest Science, 50, 186-202.

[17] Merilä, J. and Crnokrak, P. (2001) Comparison of Genetic Quantitative Differentiation at Marker Loci and Features. Journal of Evolutionary Biology, 14, 892-903.

[18] Endler, J.A. (1986) Natural Selection in the Wild. Princeton University Press, Princeton.

[19] Lumaret, R., Mir, C., Michaud, H. and Raynal, V. (2002) Phylogeographical Variation of Chloroplast DNA in Holm Oak (Quercus ilex L.). Molecular Ecology, 11, 2327-2336. http://dx.doi.org/10.1046/j.1365-294X.2002.01611.x

[20] Gathy, P. (1969) Cozrtributiorz n l'étude de la génétique des chênes (Quercus sessiliflora Salisb. et Quercus pedunculata Ehrlr.). 2' consultation mondiale sur l'amélioration des arbres forestiers. FAO, 2, 979-987.

[21] Jones, E.W. (1959) Biological Flora of the British Isles, Quercus petraea (Matt.) Liebl. Journal of Ecology, 47, 169222.

[22] Beer, R. (1981) Comportement écologique et sylvicole des chênes pédonculés (Quercus robur) rouvre (Querczrc petrnea) dans lu canton de Genève: Conséquences sur le choix des essences pour l'amélioration de la chênaie genevoise. SB Ia Iuresa, 12, 91-116.

[23] Krahl-Urban, J., Kanitz, H.R. and Punin, W. (1955) Uber den Nachweis von Agglutininen an Früchten und Blâttern der Stiel. Zeitschrift fiir Forstgenetik, 4, 18-20.

[24] Jensen, R.J., Hokanson, S.C., Isebrands, J.G. and Hancock, J.F. (1993) Morphometric Variation in Oaks of the Apostle Islands in Wisconsin: Evidence of Hybridization between Quercus rubra and Q. ellipsoidalis (Fagaceae). American Journal of Botany, 80, 1358-1366. http://dx.doi.org/10.2307/2445721

[25] Dumolin-Lapegue, S., Kremer, A. and Petit, R.J. (1999) Are Chloroplast and Mitochondrial DNA Variation Species Independent in Oaks? Evolution, 53, 1406-1413. http://dx.doi.org/10.2307/2640887 
Scientific Research Publishing (SCIRP) is one of the largest Open Access journal publishers. It is currently publishing more than 200 open access, online, peer-reviewed journals covering a wide range of academic disciplines. SCIRP serves the worldwide academic communities and contributes to the progress and application of science with its publication.

Other selected journals from SCIRP are listed as below. Submit your manuscript to us via either submit@scirp.org or Online Submission Portal.
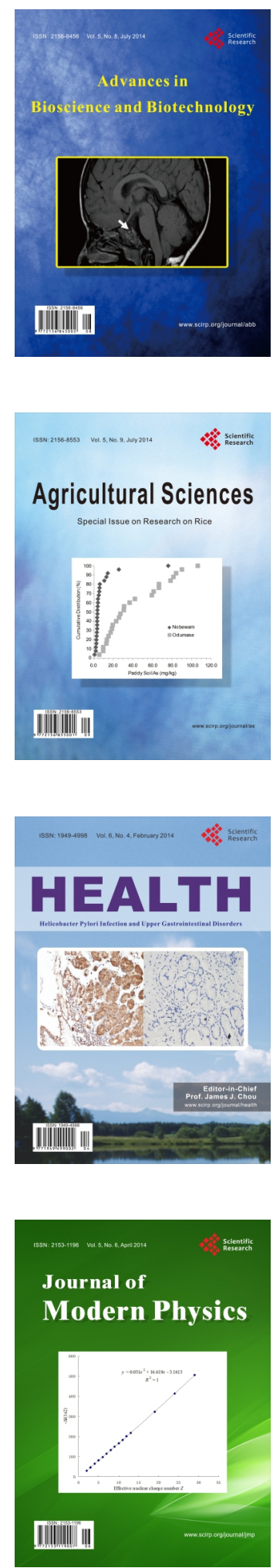
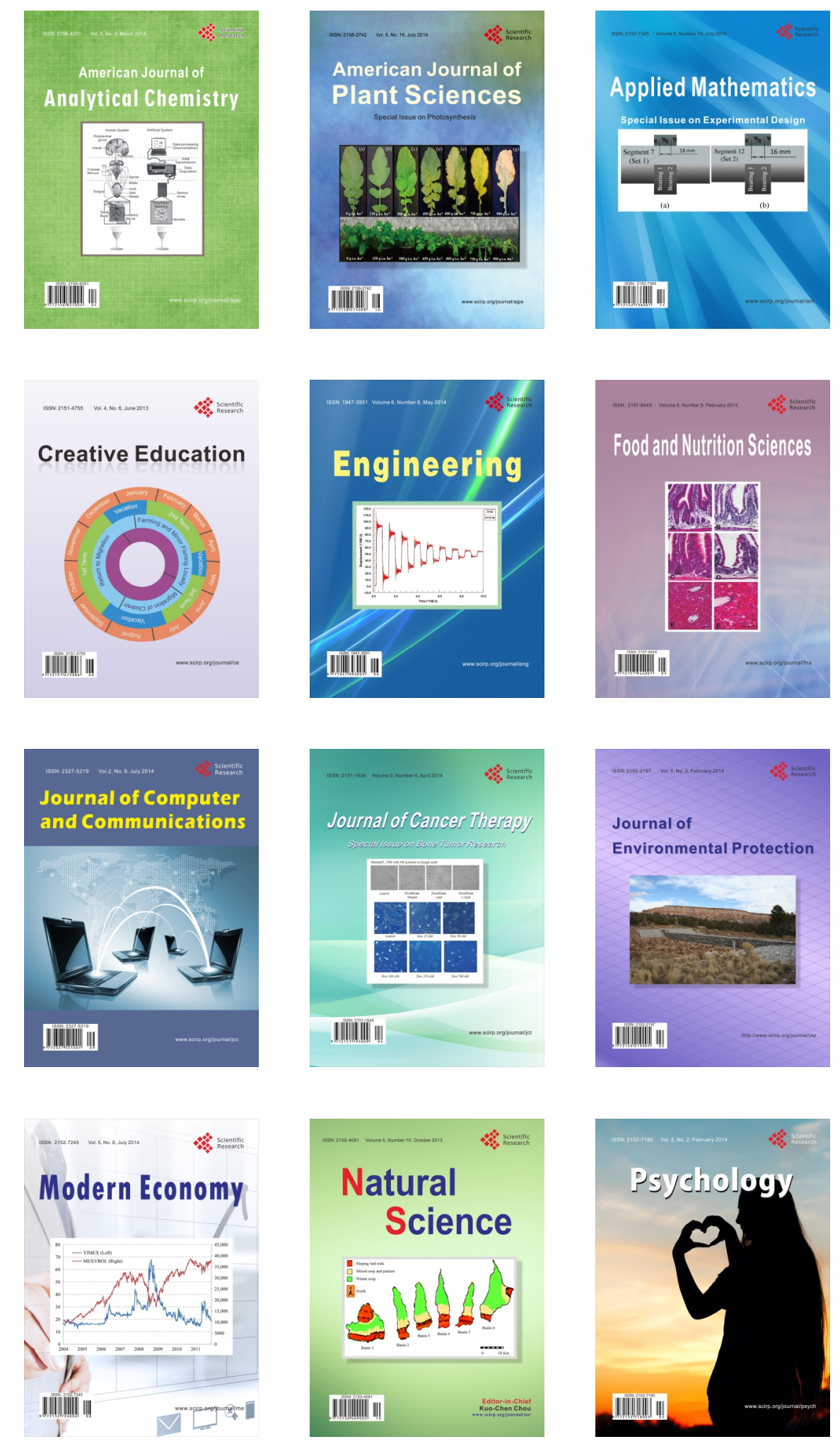